Article

\title{
Design of Indicators of Circular Economy as Instruments for the Evaluation of Sustainability and Efficiency in Wastewater from Pig Farming Industry
}

\author{
Valentín Molina-Moreno ${ }^{1, *}$, Juan Carlos Leyva-Díaz ${ }^{2}$, Francisco Javier Llorens-Montes ${ }^{1}$ and \\ Francisco Joaquín Cortés-García ${ }^{3}$ \\ 1 Department of Management, University of Granada, 18071 Granada, Spain; fllorens@ugr.es \\ 2 Department of Civil Engineering, University of Granada, 18071 Granada, Spain; jcleyva@ugr.es \\ 3 Faculty of Business and Management, Universidad Autónoma de Chile, 7500912 Santiago, Chile; \\ franciscojoaquincortesgarcia@gmail.com \\ * Correspondence: vmolina2@ugr.es; Tel.: +34-958249598
}

Received: 26 July 2017; Accepted: 28 August 2017; Published: 31 August 2017

\begin{abstract}
Circular economy intends to turn waste into resources that can be reintroduced into the production process, eliminating the negative externalities from it. The impact of pig manure on the environment is one of the main challenges in agriculture. The high amount of pig manure coming from the pig farming industry complicates the management of this type of effluents, leading to a serious impact on the environment, as it pollutes the soil, the water, and the air. The concept of the indicator of circular economy was introduced to evaluate the degree of approximation of the pig manure treatment process to the circular economy model. In light of this, these indicators showed the possibility of obtaining $0.97 \mathrm{~m}^{3}$ water $\mathrm{h}^{-1}, 49.40 \mathrm{~kg}_{\text {biofertilizer }} \mathrm{h}^{-1}$, and $5.33 \mathrm{~m}^{3}$ biogas $\mathrm{h}^{-1}$ per $1 \mathrm{~m}^{3}$ pig manure $\mathrm{h}^{-1}$ treated, allowing us to assess the minimization of waste generation and the efficiency of the use of resources. By applying an anaerobic digestion process to treat pig manure, reductions of water and natural gas consumptions were $47.01 \%$ and $5.33 \%$, respectively, which leads to a reduction in emissions of $171.98 \mathrm{~kg} \mathrm{CO}_{2} \mathrm{~h}^{-1}$. Consequently, pig manure can be considered as a technological nutrient that is reintroduced into the productive system, enabling the recovery of energy, water, and biofertilizer contained therein.
\end{abstract}

Keywords: circular economy; energy; indicator; pig manure; technological nutrient; wastewater

\section{Introduction}

Circular economy is a new development strategy aimed at the environment protection, pollution prevention, and sustainable development [1]. It is based on a conception that is either restorative or regenerative by intention and design, and whose only objective is to maximize resource efficiency and minimize waste production within the framework of economic and social sustainability [2-4].

In the circular economy model, waste is turned into resources, which are also called technological nutrients [5,6] and reintroduced into the production processes $[7,8]$. In this time of great transformations, the objective is to go from lineal economy, where society is based on waste production, consumption, and disposal, to the new model provided by circular economy, which is focused on the principles of the " 3 Rs": reduction, reutilization, and recycling of as much waste as possible. Such waste is derived from the production and consumption processes, implementing processes with circular flows of matter and energy where the utilization of raw material and energy is carried out in numerous stages $[9,10]$. Consequently, under this concept of circular economy, the consumption of matter and energy, as well as the environmental degradation are minimized without limiting social or economic growth and technological progress [11]. 
In this regard, the water industry, and more specifically the wastewater one, has been quite revolutionary in its approach towards the circular economy model due to the importance of water in relation to human life and the energy and matter it contains [12,13]. In this way, wastewater is not considered a waste but a valuable non-conventional resource, since it contains water and nutrients, such as nitrogen, phosphorus, and organic matter [14]. The recovery of wastewater components for their reuse has economic and environmental benefits [15].

One of the most important challenges that the circular economy has to develop, which is also indicated by European Union, is the necessity of designing indicators that allow for assessing the advance obtained regarding the efficiency in terms of reduction, reutilization, and recycling of waste generated in the linear economy model. The indicators of circular economy are useful in order to determine the degree of approximation of any specific process to the circular economy model.

The impact of pig manure on the environment is one of the main challenges faced by the pig farming industry. More specifically, pig population in Spain rose to 28.3 million head in 2015. Consequently, Spain became the country with the highest pig population in the European Union for the first time, with an average pig manure production of $7 \mathrm{~L} \mathrm{head}^{-1}$ day $^{-1}$, and a pig manure generation of $200,000 \mathrm{~m}^{3}$ day $^{-1}$ [16]. It can make us understand the magnitude of the problem. The high amount of pig manure coming from the pig industry complicates the management of this type of effluents, leading to a serious impact on the environment, since it pollutes the soil, the water, and the air. It also poses a risk for the human being and the local wildlife [17]. Thus, sustainable development plays an important role in pig farming industry [18].

Denmark, France, Germany, Holland, Poland, and Spain represent more than two-thirds of the total pig production in Europe (Eurostat, December 2008 survey), which directly implies high volumes of pig manure generated as a result [19]. With proper management, pig manure can be used as fertilizer in order to provide nutrients to crops and improve soil properties by means of the addition of organic matter [20].

Regarding air pollution, methane and carbon dioxide are emitted, both being greenhouse gases contributing to global warming. In addition, foul odors are produced and there is an excessive emission of ammonia into the atmosphere by means of losses through volatilization [21,22].

In addition to an excess of nitrogen, it is also possible to find an excess of assimilable forms of phosphorus and potassium, accumulation of heavy metals ( $\mathrm{Cu}$ and $\mathrm{Zn}$ ), and salinization [19] in the soil.

Pig manure also pollutes surface and underground waters, as its content in nitrates and phosphates can contribute to some phenomena, such as water eutrophication, which causes a decline in its quality [19,23-25].

Regarding hygienic-sanitary risks, gas emissions (sulfhydric, mercaptans, ammonia...) and the presence of pathogens could cause significant impacts on human and animal health due to direct toxicity and smelling aggression [19,26-29].

Consequently, it is necessary to develop and introduce systems of pig manure treatment before its spillage [30]. In this regard, anaerobic digestion stands as an appropriate process that has been widely used in pig manure treatment. This process is carried out by means of a biochemical process comprising of several stages and different types of microorganisms [31]. During such treatment, the complex organic matter contained in pig manure is hydrolyzed, fermented, and reduced to methane and carbon dioxide [32,33]. It is necessary to control different factors in this process, such as the influent characterization, microbial biomass, temperature, presence of inhibitors, mixing conditions, $\mathrm{pH}$ levels, and trace elements [34]. Thus, it should be pointed out its ability to produce renewable energy sources, such as biogas, with the subsequent reduction in the emissions of organic pollutants and greenhouse gases (GHG) [35]. In light of this, the obtaining of biogas contributes to the achievement of sustainable energy systems [6,36]. Moreover, biogas plays an important role in the decarbonization of the energy sector in Europe, which promotes that European Biogas Association (EBA) is developing a platform 
to register the biogas at national level, and to remove the boundary barriers, thus encouraging the domestic market.

In this regard, the principles of Life Cycle Assessment (LCA) methodology have been followed in the literature as a basis for the environmental assessment of the impact caused by different pork production systems in Europe and outside its boundaries [37,38]. All of the environmental analyses aim at assessing GHG emissions in order to reduce the climate change related impacts as one of the main requirements for sustainable production $[37,39,40]$. In this sense, there is a growing need to meet the European Union Climate Action targets, which aim to reduce GHG emissions to $40 \%$ of the 1990 levels by 2030 [41]. In addition to this, the environmental evaluation within the framework of this research area also includes carbon and water footprints, which are selected as indicators of primary interest for companies in the sector [37,42].

Therefore, this study is focused on the development and evaluation of indicators of circular economy as applied to pig manure management from an environmental point of view, and as a first case of implementation in pig production, a sector of particular importance in Spain. This research could supply information of interest to companies in the sector that contributes to the development of LCA methodology and carbon and water footprints.

\section{Materials and Methods}

\subsection{Description of the Pig Manure Treatment Plant}

The pig manure treatment plant occupies a smallholding with a surface of $19,000 \mathrm{~m}^{2}$. The anaerobic digestion plant used for pig manure treatment treats a pig manure flow rate $\left(\mathrm{Q}_{\mathrm{sw}}\right)$ of $120,000 \mathrm{~m}^{3}$ year $^{-1}$, for an operation time of $8000 \mathrm{~h} \mathrm{year}^{-1}$, with the characteristics shown in Table 1 .

Table 1. Influent characterization of the treatment plant.

\begin{tabular}{cc}
\hline Parameter & Value \\
\hline Treatment flow $\left(\mathrm{m}^{3}\right.$ year $\left.^{-1}\right)$ & 120,000 \\
$\mathrm{Q}_{\mathrm{sw}}\left(\mathrm{m}^{3} \mathrm{~h}^{-1}\right)$ & $15\left(8000 \mathrm{~h} \mathrm{year}^{-1}\right)$ \\
Temperature $\left({ }^{\circ} \mathrm{C}\right)$ & 15 \\
$\mathrm{pH}$ & 6 \\
Water $(\%)$ & 96 \\
Dry matter $(\%)$ & 4 \\
Electrical conductivity $\left(\mu \mathrm{S} \mathrm{cm}^{-1}\right)$ & 12,140 \\
Density $\left(\mathrm{g} \mathrm{L}^{-1}\right)$ & 1040 \\
COD $\left(\mathrm{mg} \mathrm{O}_{2} \mathrm{~L}^{-1}\right)$ & 24,000 \\
BOD $\left(\mathrm{mg} \mathrm{O}_{2} \mathrm{~L}^{-1}\right)$ & 9500 \\
Suspended solids $\left(\mathrm{mg} \mathrm{L}^{-1}\right)$ & 7200 \\
Volatile solids $\left(\mathrm{mg} \mathrm{L}^{-1}\right)$ & 6000 \\
Phosphorus $\left(\mathrm{mg} \mathrm{L}^{-1}\right)$ & 6000 \\
Kjeldahl nitrogen $\left(\mathrm{mg} \mathrm{L}^{-1}\right)$ & 9500 \\
Potassium $\left(\mathrm{mg} \mathrm{L}^{-1}\right)$ & 7200 \\
\hline
\end{tabular}

The process of pig manure treatment through anaerobic digestion includes several stages, such as pig manure pretreatment, anaerobic digestion, biogas cleaning and conditioning, and digestate treatment (Figure 1). 


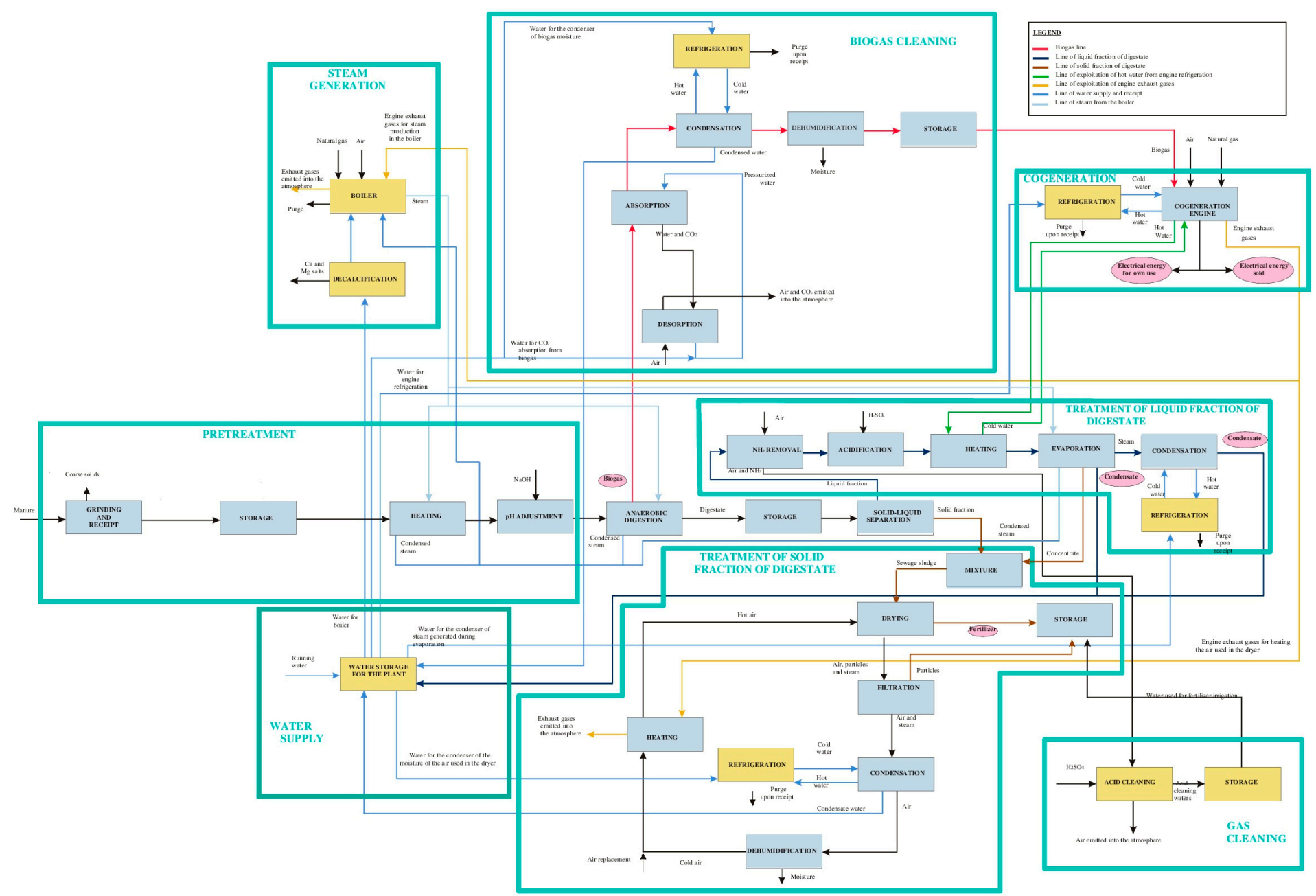

Figure 1. Flowchart of the pig manure treatment plant. 


\subsubsection{Pretreatment}

Pig manure unloading into the reception pit is carried out through a metal sieve, which is used to separate coarse solids from wastewater. Those solids are then removed by an authorized manager.

Afterwards, the supply flow must be conditioned before entering the anaerobic digester. This conditioning consists on reaching a temperature within the mesophilic range $\left(35^{\circ} \mathrm{C}\right)$, by means of a heating process, and a $\mathrm{pH}$ value between 6.5 and 7.5 , by means of the addition of sodium hydroxide.

Table 2 shows the operation conditions of the different pretreatment stages.

Table 2. Operation conditions during pretreatment stage.

\begin{tabular}{ccc}
\hline Process & Equipment & Operating Conditions \\
\hline Filtering & Sieve & Opening mesh $=10 \mathrm{~mm}$ \\
Reception & Pit & $\mathrm{V}=80 \mathrm{~m}^{3}$ \\
Storage & Tank & $\mathrm{V}_{1}=\mathrm{V}_{2}=450 \mathrm{~m}^{3}$ \\
Heating & Heat exchanger & $\mathrm{m}_{\text {steam }}=560 \mathrm{~kg} \mathrm{~h}^{-1} ; \mathrm{A}=4 \mathrm{~m}^{2}$ \\
$\mathrm{pH}$ adjustment & Tank & $\mathrm{V}=1 \mathrm{~m}^{3}$ \\
\hline
\end{tabular}

\subsubsection{Anaerobic Digestion}

Table 3 shows the operation conditions for the three anaerobic digesters, whose heating system consisting on a perimeter pipe is also characterized by means of the heating steam flow and the necessary heat exchange surface.

Table 3. Operation conditions during the stage of anaerobic digestion.

\begin{tabular}{ccc}
\hline Process & Equipment & Operating Conditions \\
\hline \multirow{2}{*}{ Anaerobic digestion } & Anaerobic digester & $\mathrm{V}_{1}=\mathrm{V}_{2}=\mathrm{V}_{3}=4100 \mathrm{~m}^{3} ; \mathrm{HRT}=28$ days; $\mathrm{T}=35^{\circ} \mathrm{C} ;$ \\
& $\mathrm{m}_{\text {steam }}=680 \mathrm{~kg} \mathrm{~h}^{-1} ; \mathrm{A}=11 \mathrm{~m}^{2}$ \\
\hline
\end{tabular}

\subsubsection{Biogas Cleaning and Conditioning}

Table 4 shows the different cleaning and conditioning processes of the biogas, which is used as fuel for the motor-generator in order to obtain electrical energy.

Table 4. Operation conditions during the stage of biogas cleaning and conditioning.

\begin{tabular}{ccc}
\hline Process & Equipment & Operating Conditions \\
\hline Absorption & Packed column & $\mathrm{m}_{\text {water }}=28 \mathrm{~kg} \mathrm{~h}^{-1} ; \mathrm{d}=0.90 \mathrm{~m} ; \mathrm{H}=2.25 \mathrm{~m}$ \\
Desorption & Packed column & $\mathrm{m}_{\text {air }}=18 \mathrm{~kg} \mathrm{~h}^{-1} ; \mathrm{d}=1.50 \mathrm{~m} ; \mathrm{H}=3.50 \mathrm{~m}$ \\
Condensation & Heat exchanger & $\mathrm{m}_{\text {water }}=1 \mathrm{~m}^{3} \mathrm{~h}^{-1} ; \mathrm{A}=0.3 \mathrm{~m}^{2}$ \\
Storage & Gasometer & $\mathrm{V}=2100 \mathrm{~m}^{3} ; \mathrm{t}_{\text {retention }}=27 \mathrm{~h} ; \mathrm{P}=2.50 \mathrm{~atm}$ \\
\hline
\end{tabular}

\subsubsection{Digestate Treatment}

Table 5 shows the different treatment processes for the liquid and the solid fractions of digestate, aimed at obtaining water and biofertilizer, respectively. 
Table 5. Operation conditions during the stage of digestate treatment.

\begin{tabular}{|c|c|c|}
\hline Process & Equipment & Operating Conditions \\
\hline Storage & Tank & $\mathrm{V}=225 \mathrm{~m}^{3}$ \\
\hline Solid-liquid separation & Centrifugal decanter & $\mathrm{m}_{\text {solid,fraction }}=2000 \mathrm{~kg} \mathrm{~h}^{-1} ; \mathrm{m}_{\text {liquid,fraction }}=13,600 \mathrm{~kg} \mathrm{~h}^{-1}$ \\
\hline \multicolumn{3}{|c|}{ Liquid Fraction } \\
\hline $\mathrm{NH}_{3}$ removal & Absorption column & $\mathrm{m}_{\text {air }}=10,200 \mathrm{~kg} \mathrm{~h}^{-1} ; \mathrm{d}=1.50 \mathrm{~m} ; \mathrm{H}=3.75 \mathrm{~m}$ \\
\hline Acidification & Tank & $\mathrm{V}=25 \mathrm{~m}^{3}$ \\
\hline Heating & Heat exchanger & $\mathrm{m}_{\text {water }}=216,000 \mathrm{~kg} \mathrm{~h}^{-1} ; \mathrm{A}=21 \mathrm{~m}^{2}$ \\
\hline Evaporation & Evaporator & $\mathrm{A}_{1}=\mathrm{A}_{2}=45 \mathrm{~m}^{2}$ \\
\hline Condensation & Heat exchanger & $\mathrm{m}_{\text {water }}=400,000 \mathrm{~kg} \mathrm{~h}^{-1} ; \mathrm{A}=490 \mathrm{~m}^{2}$ \\
\hline \multicolumn{3}{|c|}{ Solid Fraction } \\
\hline Mixture & Mixer & $\mathrm{V}=28 \mathrm{~m}^{3} ; \mathrm{m}_{\text {outlet }}=2500 \mathrm{~kg} \mathrm{~h}^{-1}$ \\
\hline Drying & Dryer & $\mathrm{m}_{\text {air }}=62,000 \mathrm{~kg} \mathrm{~h}^{-1} ; \mathrm{d}=2.5 \mathrm{~m} ; \mathrm{H}=3 \mathrm{~m}$ \\
\hline Filtration & Bag filter & $\mathrm{A}=250 \mathrm{~m}^{2}$ \\
\hline Storage & Storage location & $\mathrm{L}=20 \mathrm{~m} ; \mathrm{A}=10 \mathrm{~m} ; \mathrm{H}=5 \mathrm{~m}$ \\
\hline Condensation & Heat exchanger & $\mathrm{m}_{\text {water }}=140 \mathrm{~m}^{3} \mathrm{~h}^{-1} ; \mathrm{A}=65 \mathrm{~m}^{2}$ \\
\hline
\end{tabular}

\subsection{Indicators of Circular Economy}

Several indicators of circular economy that allow to determine the efficiency of the use of resources, the minimization of waste generation and the conversion of pig manure into a technological nutrient are defined hereafter $[5,6]$. These indicators are considered within the circular economy model applied to the process of pig manure treatment.

Such indicators will be defined in relation to the three resources that are recovered from pig manure during the process: water, biofertilizer, and biogas (Figure 1).

\subsubsection{Indicators of Circular Economy for Water}

The indicator of circular economy efficiency for water $\left(\mathrm{I}_{\mathrm{w}, \mathrm{ce}}\right)$ provides information about the reduction in the water used for pig manure treatment.

Such indicator is defined according to Equation (1):

$$
\mathrm{I}_{\mathrm{w}, \mathrm{ce}}=\frac{\sum_{\mathrm{i}=1}^{\mathrm{n}} \mathrm{Q}_{\mathrm{w}, \mathrm{i}}}{\mathrm{Q}_{\mathrm{w}, \mathrm{t}}} \cdot 100
$$

where $Q_{W, i}$ is the volumetric flow rate of water recovered during stage $i$ in the process of pig manure treatment, and $\mathrm{Q}_{\mathrm{w}, \mathrm{t}}$ is the total volumetric flow rate of water used during the process of pig manure treatment.

This indicator can range between $0 \%$ and $100 \% .0$ means that no water was recovered during the process and $100 \%$ is the ideal case of sustainability, where there is such recovery of water during the process that no external consumption occurs.

In addition, an indicator of technological nutrient performance for water $\left(\mathrm{I}_{\mathrm{W}, \mathrm{tn}}\right)$ is defined according to Equation (2):

$$
\mathrm{I}_{\mathrm{w}, \mathrm{tn}}=\frac{\sum_{\mathrm{i}=1}^{\mathrm{n}} \mathrm{Q}_{\mathrm{w}, \mathrm{i}}}{\mathrm{Q}_{\mathrm{sw}}}
$$

where $Q_{s w}$ is the volumetric flow rate of pig manure treated during the process.

This indicator provides information about the water volume that can be obtained and reintroduced into the process according to the pig manure volume (technological nutrient) that is treated in the plant.

\subsubsection{Indicators of Circular Economy for Biofertilizer}

The indicator of circular economy efficiency for the biofertilizer $\left(\mathrm{I}_{\mathrm{bf}, \mathrm{ce}}\right)$ provides information about the production of biofertilizer during the process of pig manure treatment. 
Such an indicator is defined according to Equation (3):

$$
\mathrm{I}_{\mathrm{bf}, \mathrm{ce}}=\frac{\sum_{\mathrm{i}=1}^{\mathrm{n}} \mathrm{m}_{\mathrm{bf}, \mathrm{i}}}{\mathrm{m}_{\text {digestate }}} \cdot 100
$$

where $m_{b f, i}$ is the mass flow rate of biofertilizer obtained during stage $i$ of the process of pig manure treatment, and $\mathrm{m}_{\text {digestate }}$ is the mass flow rate of digestate generated during the anaerobic digestion stage.

This indicator can range between 0 and values below $100 \%$, indicating the production rate of the biofertilizer during the process.

The indicator of technological nutrient performance for the biofertilizer $\left(\mathrm{I}_{\mathrm{bf}, \mathrm{tn}}\right)$ can be defined as shown in Equation (4):

$$
\mathrm{I}_{\mathrm{bf}, \mathrm{tn}}=\frac{\sum_{\mathrm{i}=1}^{\mathrm{n}} \mathrm{m}_{\mathrm{bf}, \mathrm{i}}}{\mathrm{Q}_{\mathrm{sw}}}
$$

This indicator provides information about the amount of biofertilizer generated during the treatment process with respect to the volume of pig manure that will be treated in the plant.

\subsubsection{Indicators of Circular Economy for Biogas}

The indicator of circular economy efficiency for biogas $\left(\mathrm{I}_{\mathrm{bg}, \mathrm{ce}}\right)$ provides information about the reduction in natural gas consumption in order to carry out pig manure treatment.

Such an indicator is defined according to Equation (5):

$$
\mathrm{I}_{\mathrm{bg}, \mathrm{ce}}=\frac{\mathrm{Q}_{\mathrm{bg}, \text { treated }}}{\mathrm{Q}_{\mathrm{ng}, \mathrm{t}}} \cdot 100
$$

where $\mathrm{Q}_{\mathrm{bg} \text {,treated }}$ is the volumetric flow rate of biogas recovered during the process of pig manure treatment and $Q_{n g, t}$ is the volumetric flow rate of natural gas used during the process of pig manure treatment.

This indicator can range between $0 \%$ and $100 \% .0$ means that no biogas was recovered during the process and $100 \%$ is the ideal case of sustainability, where the biogas flow rate recovered is the same as the one used in the treatment plant.

The indicator of technological nutrient performance for the biogas $\left(\mathrm{I}_{\mathrm{bg}, \mathrm{tn}}\right)$ can be defined as shown in Equation (6):

$$
\mathrm{I}_{\mathrm{bg}, \mathrm{tn}}=\frac{\mathrm{Q}_{\mathrm{bg}, \text { treated }}}{\mathrm{Q}_{\mathrm{sw}}}
$$

This parameter indicates the volume of biogas generated during the anaerobic digestion treatment depending on the volume of pig manure treated in the plant.

The reduction in $\mathrm{CO}_{2}$ emissions $\left(\mathrm{ER}_{\mathrm{CO} 2, \mathrm{ce}}\right)$ as a consequence of the use of biogas during the process can be calculated from $\mathrm{Q}_{\mathrm{ng}, \mathrm{t}}$, the factor of $\mathrm{CO}_{2}$ emissions of natural gas $\left(\mathrm{EF}_{\mathrm{CO}, \mathrm{ng}}\right)$ and $\mathrm{I}_{\mathrm{bg}, \mathrm{ce}}$, as shown in Equation (7):

$$
\mathrm{ER}_{\mathrm{CO} 2, \mathrm{ce}}=\mathrm{Q}_{\mathrm{ng}, \mathrm{t}} \cdot \mathrm{EF}_{\mathrm{CO} 2, \mathrm{ng}} \cdot \mathrm{I}_{\mathrm{bg}, \mathrm{ce}}
$$

\section{Results and Discussion}

\subsection{Water Production}

The water needs of the plant come from the stages of biogas absorption, the steam generation boiler, and the cooling towers of the condenser of the steam contained in the biogas, cogeneration engine, condenser of the steam generated during evaporation, and condenser of the steam contained in the air used during the drying process. On the contrary, that water generated during the process comes from three subprocesses, such as evaporation, condensation of the steam contained in the air used 
during the drying process, and condensation of the steam contained in the biogas obtained during anaerobic digestion. Table 6 shows the values of water consumption and generation.

Table 6. Processes of the treatment plant where water is used and generated.

\begin{tabular}{|c|c|}
\hline Process & Water Flow $\left(\mathrm{m}^{3} \mathrm{~h}^{-1}\right)$ \\
\hline \multicolumn{2}{|l|}{ Consumption } \\
\hline Biogas absorption & 0.35 \\
\hline Cooling tower of the condenser of the steam contained in the biogas & 0.02 \\
\hline Cooling tower of the cogeneration engine & 4.02 \\
\hline Cooling tower of the condenser of the steam generated during evaporation & 20.00 \\
\hline $\begin{array}{c}\text { Cooling tower of the condenser of the steam contained in the air used during the drying } \\
\text { process }\end{array}$ & 6.70 \\
\hline Steam generation boiler & 0.01 \\
\hline $\mathrm{Q}_{\mathrm{w}, \mathrm{t}}$ & 31.10 \\
\hline \multicolumn{2}{|l|}{ Generation } \\
\hline Evaporation (1) & 12.80 \\
\hline Condensation of the steam contained in the air used during the drying process (2) & 1.80 \\
\hline Condensation of the steam contained in the biogas obtained during anaerobic digestion (3) & 0.02 \\
\hline$\sum_{i=1}^{3} Q_{w, i}$ & 14.62 \\
\hline
\end{tabular}

The higher water generation is due to the evaporation process of the treatment of liquid fraction of digestate, with a value of $12.80 \mathrm{~m}^{3} \mathrm{~h}^{-1}$ (Table 6).

\subsection{Biofertilizer Production}

The value of the digestate mass flow rate obtained during the stage of anaerobic digestion is $\mathrm{m}_{\text {digestate }}=15,600 \mathrm{~kg} \mathrm{~h}^{-1}$. Biofertilizer will be obtained from it. Table 7 shows the stages of the process where it is generated.

Table 7. Processes of the treatment plant during which biofertilizer is produced.

\begin{tabular}{cc}
\hline Process & Biofertilizer Flow $\left(\mathbf{k g ~ h}^{-\mathbf{1}}\right)$ \\
\hline Drying (1) & 561.00 \\
Filtration (2) & 60.00 \\
Gas cleaning (3) & 120.00 \\
$\sum_{\boldsymbol{i = 1}}^{3} m_{b f, i}$ & $\mathbf{7 4 1 . 0 0}$ \\
\hline
\end{tabular}

As shown in Table 7, the highest production of fertilizer is carried out during the drying stage of that sewage sludge resulting from the mixture of the solid fraction of digestate and the concentrate of the evaporation process corresponding to the treatment of liquid fraction of digestate (Figure 1). The fertilizer obtained during the filtration stage corresponds to the particles that may be contained in the air used during the drying process, this is why its value is lower. Regarding the gas cleaning stage, liquid fertilizer enriched with ammonium sulfate is obtained, with which the solid biofertilizer from the two previous stages is irrigated.

\subsection{Biogas Production}

Natural gas consumption in the pig manure treatment plant comes from the stage of steam generation in the boiler as well as the cogeneration stage. Biogas production is carried out during the anaerobic digestion stage. This biogas undergoes a purification process so that it can be used in the cogeneration process (Figure 1). Table 8 shows the natural gas consumption and biogas production values. 
Table 8. Processes of the treatment plant during which water is used and generated.

\begin{tabular}{cc}
\hline Process & Gas Flow $\left(\mathbf{m}^{\mathbf{3}} \mathbf{h}^{-\mathbf{1}}\right)$ \\
\hline & Consumption \\
\hline Steam generation boiler & 473.75 \\
Cogeneration engine & 1027.00 \\
$\mathbf{Q}_{\mathbf{n g}, \mathbf{t}}$ & $\mathbf{1 5 0 0 . 7 5}$ \\
\hline & Generation \\
\hline Anaerobic digestion & \\
$\mathbf{Q}_{\mathbf{b g}, \text { treated }}$ & 80.00 \\
\hline
\end{tabular}

\subsection{Indicators of Circular Economy}

Table 9 shows the values of the six indicators of circular economy evaluated for the process of pig manure treatment.

Table 9. Indicators of circular economy efficiency and technological nutrient performance for water, biofertilizer and biogas produced during the process of pig manure treatment. $\mathrm{I}_{\mathrm{w}, \mathrm{ce}}$ (indicator of circular economy efficiency for water), $\mathrm{I}_{\mathrm{w}, \mathrm{tn}}$ (indicator of technological nutrient performance for water), $\mathrm{I}_{\mathrm{bf}, \mathrm{ce}}$ (indicator of circular economy efficiency for biofertilizer), $\mathrm{I}_{\mathrm{bf}, \text { tn }}$ (indicator of technological nutrient performance for biofertilizer), $\mathrm{I}_{\mathrm{bg}, \mathrm{ce}}$ (indicator of circular economy efficiency for biogas), $\mathrm{I}_{\mathrm{bg}, \mathrm{tn}}$ (indicator of technological nutrient performance for biogas), $\mathrm{ER}_{\mathrm{CO} 2 \text {,ce }}$ (reduction in $\mathrm{CO}_{2}$ emissions as a consequence of the application of circular economy).

\begin{tabular}{|c|c|}
\hline Indicator of Circular Economy & Value \\
\hline \multicolumn{2}{|l|}{ Water } \\
\hline $\mathrm{I}_{\mathrm{W}, \mathrm{ce}}(\%)$ & 47.01 \\
\hline $\mathrm{I}_{\mathrm{w}, \mathrm{tn}}\left(\mathrm{m}^{3}\right.$ water $\mathrm{m}^{-3}$ pig manure $)$ & 0.97 \\
\hline \multicolumn{2}{|c|}{ Biofertilizer } \\
\hline $\mathrm{I}_{\mathrm{bf}, \mathrm{ce}}(\%)$ & 4.75 \\
\hline $\mathrm{I}_{\mathrm{bf}, \mathrm{tn}}\left(\mathrm{kg}\right.$ biofertilizer $\mathrm{m}^{-3}$ pig manure $)$ & 49.40 \\
\hline \multicolumn{2}{|l|}{ Biogas } \\
\hline $\mathrm{I}_{\mathrm{bg}, \mathrm{ce}}(\%)$ & 5.33 \\
\hline $\mathrm{I}_{\mathrm{bg}, \mathrm{tn}}\left(\mathrm{m}^{3}\right.$ biogas $\mathrm{m}^{-3}$ pig manure $)$ & 5.33 \\
\hline $\mathrm{ER}_{\mathrm{CO} 2, \mathrm{ce}}\left(\mathrm{kg} \mathrm{CO}_{2} \mathrm{~h}^{-1}\right)^{(1)}$ & 171.98 \\
\hline
\end{tabular}

As shown in Table 9, the treatment process allows water, biofertilizer, and biogas recovery from pig manure, turned into a technological nutrient. The water obtained allows for the reduction of water consumption for such process by $47.01 \%$, the biogas obtained allows to the reduction of natural gas consumption by $5.33 \%$, and, on top of that, $4.75 \%$ biofertilizer is produced from the digestate obtained during the anaerobic digestion stage.

Furthermore, those indicators of technological nutrient production indicate that per $1 \mathrm{~m}^{3}$ pig manure $\mathrm{h}^{-1}$ treated, it is possible to obtain $0.97 \mathrm{~m}^{3}$ water $\mathrm{h}^{-1}, 49.40 \mathrm{~kg}$ biofertilizer $\mathrm{h}^{-1}$, and $5.33 \mathrm{~m}^{3}$ biogas $\mathrm{h}^{-1}$. Obtaining such a quantity of biogas leads to a reduction in emissions of $171.98 \mathrm{~kg} \mathrm{CO}_{2} \mathrm{~h}^{-1}$. In light of this, Table 10 shows the biogas production potential reported in several works all over the world. 
Table 10. Summary of literature findings comparing the biogas production potential during anaerobic digestion of pig manure.

\begin{tabular}{ccc}
\hline Zone & Biogas Production Potential & References \\
\hline South Africa & $18.72 \mathrm{~m}^{3}$ biogas $\mathrm{m}^{-3}$ pig manure & {$[44]$} \\
China & $6.38 \mathrm{~m}^{3}$ biogas $\mathrm{m}^{-3}$ pig manure & {$[45]$} \\
China & $1.43-2.15 \mathrm{~m}^{3}$ biogas $\mathrm{m}^{-3}$ pig manure & {$[46]$} \\
Australia & $0.480 \mathrm{~m}^{3}$ biogas $\mathrm{kg}^{-1} \mathrm{VS}$ & {$[47]$} \\
Spain & $0.170 \mathrm{~m}^{3}$ biogas $\mathrm{kg}^{-1} \mathrm{VS}$ & {$[48]$} \\
South Korea & $0.242 \mathrm{~m}^{3}$ biogas kg $\mathrm{kg}^{-1} \mathrm{VS}$ & {$[49]$} \\
South Korea & $0.394 \mathrm{~m}^{3}$ biogas $\mathrm{kg}^{-1} \mathrm{VS}$ & {$[50]$} \\
Colombia & $0.437 \mathrm{~m}^{3}$ biogas $\mathrm{kg}^{-1} \mathrm{VS}$ & {$[51]$} \\
\hline
\end{tabular}

In the present research, $\mathrm{I}_{\mathrm{bg}, \mathrm{tn}}$ shows a value of $5.33 \mathrm{~m}^{3}$ biogas $\mathrm{m}^{-3}$ pig manure (or $0.888 \mathrm{~m}^{3}$ biogas $\mathrm{kg}^{-1} \mathrm{VS}$ ) that is within the range found in literature. It should be highlighted that the biogas production potential is higher than the different works included in Table 10, with the exception of the studies that were carried out in South Africa $\left(18.72 \mathrm{~m}^{3}\right.$ biogas $\mathrm{m}^{-3}$ pig manure) and China $\left(6.38 \mathrm{~m}^{3}\right.$ biogas $\mathrm{m}^{-3}$ pig manure).

The values obtained for the indicators of circular economy efficiency and technological nutrient performance bring to light the importance of the application of the circular economy model in pig manure treatment. In this regard, the proposal of these indicators has been considered due to its significant weight in the process of pig manure treatment. In this way, those responsible for making decisions in these treatment processes can have access to these indicators and make operational decisions in that sector in order to make it generate as few negative externalities as possible and be under way to a circular economy production model. Thus, the introduction of the indicators of circular economy in the present work could facilitate the development of new strategies for pig manure treatment concerning the reduction in waste generation and the consumption of renewable energy, according to the requirements of the European Union.

\section{Conclusions}

The present article provides the first indicators for circular economy efficiency, as well as tools for technological nutrient performance for the pig farming industry, allowing the quantification of the degree of approximation to a circular economy model.

This study explains that pig manure can be considered as a technological nutrient that can also be reintroduced into the production system, enabling the recovery of those resources present during such processes, such as water, nutrients, and energy, from a treatment process whose central nucleus is anaerobic digestion. Such resources are used in the process itself, as in the case of water, reducing water consumption by $47.01 \%$, biogas, reducing gas natural consumption by $5.33 \%$, and some other products resulting directly from this type of industrial activity, as in the case of the biofertilizer. In addition, the treatment process allows the recovery of $0.97 \mathrm{~m}^{3}$ water $\mathrm{m}^{-3}$ pig manure, $49.40 \mathrm{~kg}$ biofertilizer $\mathrm{m}^{-3}$ pig manure, and $5.33 \mathrm{~m}^{3}$ biogas $\mathrm{m}^{-3}$ pig manure. In this way, the proposed indicators can be taken into account by the production plant managers in order to improve the efficiency of the use of resources and the minimization of waste generation.

Consequently, this research provides the pig farming industry with new ideas and measuring tools so that it becomes a reference in sustainable production and contributes to reduce the negative polluting effects, in environmental terms, of pig manure generation. This article provides relevant details so that pig industry can develop strategies for pig manure treatment in compliance with the new requirements of the European Union in relation to waste generation in 2020 and renewable energy consumption in 2030 (27\%), and, in this way, being able to comply with this regulation, which highlights the importance of the circular economy. In addition, it is also a way of incorporating innovations in its 
processes to make it more sustainable from the environmental point of view, contributing to a higher effectiveness in terms of a decrease of negative externalities.

Acknowledgments: This study has been supported and co-financed by projects from the Spanish Ministry of Economy and Competitiveness ECO2010-15885 and ECO2013-47027-P, Andalusian Government P11-SEJ-7294 and European Union (ERDF funds).

Author Contributions: All authors participated equally in the conception and design of this research, and the elaboration of this paper. All authors read and approved the final manuscript.

Conflicts of Interest: The authors declare no conflict of interest.

\section{References}

1. Hu, J.; Xiao, Z.; Zhou, R.; Deng, W.; Wang, M.; Ma, S. Ecological utilization of leather tannery waste with circular economy model. J. Clean. Prod. 2011, 19, 221-228. [CrossRef]

2. Ellen Macarthur Foundation. Towards the Circular Economy: Economic and Business Rationale for an Accelerated Transition; Ellen Macarthur Foundation: Cowes, UK, 2013.

3. Lozano, R.; Nummert, B.; Ceulemans, K. Elucidating the relationship between sustainability reporting and organisational change management for sustainability. J. Clean. Prod. 2016, 125, 168-188. [CrossRef]

4. Urbaniec, K.; Mikulcic, H.; Duic, N.; Lozano, R. SDEWES 2014-Sustainable development of energy, water and environment systems. J. Clean. Prod. 2016, 130, 1-11. [CrossRef]

5. Molina-Moreno, V.; Leyva-Díaz, J.C.; Sánchez-Molina, J. Pellet as a technological nutrient within the circular economy model: Comparative analysis of combustion efficiency and $\mathrm{CO}$ and $\mathrm{NO}_{\mathrm{x}}$ emissions for pellets from olive and almond trees. Energies 2016, 9, 777. [CrossRef]

6. Argudo-García, J.J.; Molina-Moreno, V.; Leyva-Díaz, J.C. Valorization of sludge from drinking water treatment plants. A commitment to circular economy and sustainability. Dyna 2017, 92, 71-75.

7. Communication from the Commission to the European Parliament, the Council, the European Economic and Social Committee and the Committee of the Regions. Towards a Circular Economy: A Zero Waste Programme for Europe. 2014. 398 Final. Available online: http:/ / cor.europa.eu/en/activities/stakeholders/ Documents/COM(2014)\%20398\%20final.pdf (accessed on 13 October 2016).

8. Scheel, C. Beyond sustainability. Transforming industrial zero-valued residues into increasing economic returns. J. Clean. Prod. 2016, 131, 376-386. [CrossRef]

9. Yuan, Z.; Bi, J.; Moriguichi, Y. The circular economy; a new development strategy in China. J. Ind. Ecol. 2006, 10, 4-8. [CrossRef]

10. Ghisellini, P.; Cialani, C.; Ulgiati, S. A review on circular economy: The expected transition to a balanced interplay of environmental and economic systems. J. Clean. Prod. 2016, 114, 11-32. [CrossRef]

11. Stahel, W. Product-life factor. In An Inquiry into the Nature of Sustainable Societies; 1982; pp. 1-10. Available online: http:/ / www.product-life.org/en/major-publications/the-product-life-factor (accessed on 13 October 2016).

12. Veolia. Water at the Heart of the Circular Economy. 2014. Available online: http://www.veolia. $\mathrm{com} / \mathrm{middleeast} / \mathrm{sites} / \mathrm{g} / \mathrm{files} /$ dvc171/f/assets/documents/2014/10/Veolia_brochure_WWW_ STOCKHOLM_2014.pdf (accessed on 13 October 2016).

13. Abu-Ghunmi, D.; Abu-Ghunmi, L.; Kayal, B.; Bino, A. Circular economy and the opportunity cost of not 'closing the loop' of water industry: The case of Jordan. J. Clean. Prod. 2016, 131, 228-236. [CrossRef]

14. Werner, C.; Fall, P.A.; Schlick, J.; Mang, H. Reasons for principles of ecological sanitation. Inecosan—closing the loop. In Proceedings of the 2nd International Symposium, Lubeck, Germany, 7-11 April 2003; pp. 23-30.

15. Nghiem, L.D.; Koch, K.; Bolzonella, D.; Drewes, J.E. Full scale co-digestion of wastewater sludge and food waste: Bottlenecks and possibilities. Renew. Sustain. Energy Rev. 2017, 72, 354-362. [CrossRef]

16. Estadística Magrama, S.G. Caracterización del Sector Porcino Español Año 2015; Estadística Ministerio de Agricultura, Alimentación y Medio Ambiente: Madrid, Spain, 2015.

17. Liu, X.; Xiao, X. The optimization of cyclic links of live pig-industry chain based on circular economics. Sustainability 2016, 8, 26. [CrossRef]

18. Schodl, K.; Klein, F; Winckler, C. Mapping sustainability in pig farming research using keyword network analysis. Livest. Sci. 2017, 196, 28-35. [CrossRef] 
19. Vázquez, M.A.; de la Varga, D.; Plana, R.; Soto, M. Integrating liquid fraction of pig manure in the composting process for nutrient recovery and water re-use. J. Clean. Prod. 2015, 104, 80-89. [CrossRef]

20. Vanotti, M.B.; Szogi, A.A.; Hunt, P.G.; Millner, P.D.; Humenik, F.J. Development of environmentally superior treatment system to replace anaerobic swine lagoons in the USA. Bioresour. Technol. 2007, 98, 3184-3194. [CrossRef] [PubMed]

21. Szogi, A.A.; Vanotti, M.B.; Stansbery, A.E. Reduction of ammonia emissions from treated anaerobic swine lagoon. In Proceedings of the 2005 Animal Waste Management Symposium, NCSU, Raleigh, NC, USA, 5-7 October 2005.

22. Loughrin, J.H.; Szogi, A.A.; Vanotti, M.B. Reduction of malodorous compounds from a treated swine anaerobic lagoon. J. Environ. Qual. 2006, 35, 194-199. [CrossRef] [PubMed]

23. Mallin, M.A. Impacts of industrial animal production on rivers and estuaries. Am. Sci. 2000, 88, 26-37. [CrossRef]

24. Krapaca, I.G.; Deya, W.S.; Roya, W.R.; Smyth, C.A.; Storment, E.; Sargent, S.L.; Steele, J.D. Impacts of swine manure pits on groundwater quality. Environ. Pollut. 2002, 120, 475-492. [CrossRef]

25. Flotats, X.; Bonmati, A.; Fernandez, B.; Magri, A. Manure treatment technologies: On farm versus centralized strategies, NE Spain as case study. Bioresour. Technol. 2009, 100, 5519-5526. [CrossRef] [PubMed]

26. Sobsey, M.D.; Khatib, L.A.; Hill, V.R.; Alocilja, E.; Pillai, S. Pathogens in animal wastes and the impacts of waste management practices on their survival, transport and fate. In White Papers on Animal Agriculture and the Environment; MidWest Plan Service (MWPS), Iowa State University: Ames, IA, USA, 2001; Chapter 17.

27. Vanotti, M.B.; Millner, P.D.; Hunt, P.G.; Ellison, A.Q. Removal of pathogen and indicator microorganisms from liquid swine manure in multi-step biological and chemical treatment. Bioresour. Technol. 2005, 96, 209-214. [CrossRef] [PubMed]

28. Prapaspongsa, T.; Christensen, P.; Schmidt, J.H.; Thrane, M. LCA of comprehensive pig manure management incorporating integrated technology systems. J. Clean. Prod. 2010, 18, 1413-1422. [CrossRef]

29. Thu, C.T.T.; Cuong, P.H.; Hang, L.T.; Chao, N.V.; Anh, L.X.; Trach, N.X.; Sommer, S.G. Manure management practices on biogas and non-biogas pig farms in developing countries e using livestock farms in Vietnam as an example. J. Clean. Prod. 2012, 27, 64-71.

30. Cheng, H.; Tian, G.; Liu, J. Enhancement of biomass productivity and nutrients removal from pretreated piggery wastewater by mixotrophic cultivation of Desmodesmus sp. CHX1. Desalin. Water Treat. 2013, 51, 7004-7011. [CrossRef]

31. Duda, R.M.; Vantini, J.S.; Martins, L.S.; Varani, A.M.; Lemos, M.V.F.; Ferro, M.I.T.; de Oliveira, R.A. A balanced microbiota efficiently produces methane in a novel high-rate horizontal anaerobic reactor for the treatment of swine wastewater. Bioresour. Technol. 2015, 197, 152-160. [CrossRef] [PubMed]

32. Kim, W.; Shin, S.G.; Cho, K.; Lee, C.; Hwang, S. Performance of methanogenic reactors in temperature phased two-stage anaerobic digestion of swine wastewater. J. Biosci. Bioeng. 2012, 114, 635-639. [CrossRef] [PubMed]

33. Dennehy, C.; Lawlor, P.G.; Jiang, Y.; Gardiner, G.E.; Xie, S.; Nghiem, L.D.; Zhan, X. Greenhouse gas emissions from different pig manure management techniques: A critical analysis. Front. Environ. Sci. Eng. 2017, 11, 11. [CrossRef]

34. Ward, A.J.; Hobbs, P.J.; Holliman, P.J.; Jones, D.L. Optimisation of the anaerobic digestion of agricultural resources. Bioresour. Technol. 2008, 99, 7928-7940. [CrossRef] [PubMed]

35. Deng, L.; Yang, H.; Liu, G.; Zheng, D.; Chen, Z.; Liu, Y.; Pu, X.; Song, L.; Wang, Z.; Lei, Y. Kinetics of temperature effects and its significance to the heating strategy for anaerobic digestion of swine wastewater. Appl. Energy 2014, 134, 349-355. [CrossRef]

36. Cucchiella, F.; D’Adamo, I.; Gastaldi, M.; Koh, S.C.L.; Rosa, P. A comparison of environmental and energetic performance of European countries: A sustainability index. Renew. Sustain. Energy Rev. 2017, 78, 401-413. [CrossRef]

37. McAuliffe, G.A. A thematic review of life cycle assessment (LCA) applied to pig production. Rev. Environ. Impact Assess. 2016, 56, 12-22. [CrossRef]

38. Noya, I.; Aldea, X.; Gasol, C.M.; González-García, S.; Amores, M.J.; Colon, J.; Ponsá, S.; Roman, I.; Rubio, M.A.; Casas, E.; et al. Carbon and water footprint of pork supply chain in Catalonia: From feed to final products. J. Environ. Manag. 2016, 171, 133-143. [CrossRef] [PubMed] 
39. Nguyen, T.L.T.; Hermansen, J.E.; Mogensen, L. Fossil energy and GHG saving potentials of pig farming in the EU. Energy Policy 2010, 38, 2561-2571. [CrossRef]

40. Philippe, F.X.; Nicks, B. Review on greenhouse gas emissions from pig houses: Production of carbon dioxide, methane and nitrous oxide by animals and manure. Agric. Ecosyst. Environ. 2014, 199, 10-25. [CrossRef]

41. European Commission. EU Climate Action: Key Targets for 2030; European Commission: Bruxelles, Belgium, 2017.

42. Reckmann, K.; Traulsen, I.; Krieter, J. Environmental Impact Assessment-Methodology with special emphasis on European pork production. Rev. J. Environ. Manag. 2012, 107, 102-109. [CrossRef] [PubMed]

43. Oficina Catalana del Canvi Climàtic. Guía Práctica Para el Cálculo de Emisiones de Gases de Efecto Invernadero (GEI); Oficina Catalana del Cambio Climático: Barcelona, Spain, 2013.

44. Mugodo, K.; Magama, P.P.; Dhavu, K. Biogas Production Potential from Agricultural and Agro-Processing Waste in South Africa. Waste Biomass Valoriz. 2017. [CrossRef]

45. Li, J.; Kong, C.; Duan, Q.; Luo, T.; Mei, Z.; Lei, Y. Mass flow and energy balance plus economic analysis of a full-scale biogas plant in the rice-wine-pig system. Bioresour. Technol. 2015, 193, 62-67. [CrossRef] [PubMed]

46. Deng, L.; Zheng, P.; Chen, Z.; Mahmood, Q. Improvement in post-treatment of digested swine wastewater. Bioresour. Technol. 2008, 99, 3136-3145. [CrossRef] [PubMed]

47. Astals, S.; Musenze, R.S.; Bai, X.; Tannock, S.; Tait, S.; Pratt, S.; Jensen, P.D. Anaerobic co-digestion of pig manure and algae: Impact of intracellular algal products recovery on co-digestion performance. Bioresour. Technol. 2015, 181, 97-104. [CrossRef] [PubMed]

48. Astals, S.; Nolla-Ardèvol, V.; Mata-Alvarez, J. Thermophilic co-digestion of pig manure and crude glycerol: Process performance and digestate stability. J. Biotechnol. 2013, 166, 97-104. [CrossRef] [PubMed]

49. Zhang, L.; Lee, Y.W.; Jahng, D. Anaerobic co-digestion of food waste and piggery wastewater: Focusing on the role of trace elements. Bioresour. Technol. 2011, 102, 5048-5059. [CrossRef] [PubMed]

50. Kafle, G.K.; Kim, S.H.; Sung, K.I. Batch anaerobic co-digestion of Kimchi factory waste silage and swine manure under mesophilic conditions. Bioresour. Technol. 2012, 124, 489-494. [CrossRef] [PubMed]

51. Rodríguez, A.; Ángel, J.; Rivero, E.; Acevedo, P.; Santis, A.; Cabeza, I.; Acosta, M.; Hernández, M. Evaluation of the Biochemical Methane Potential of Pig Manure, Organic Fraction of Municipal Solid Waste and Cocoa Industry Residues in Colombia. Chem. Eng. 2017, 57, 55-60. 